\title{
INPUT AND OUTPUT CHANGES OF AN IDENTIFIED NEURAL PATHWAY ARE CORRELATED WITH ASSOCIATIVE LEARNING IN HERMISSENDA ${ }^{1}$
}

\author{
YASUMASA GOH, ${ }^{2}$ IZJA LEDERHENDLER, AND DANIEL L. ALKON ${ }^{3}$ \\ Section on Neural Systems, Laboratory of Biophysics, IRP, National Institute of Neurological and Communicative Disorders and \\ Stroke, National Institutes of Health, Marine Biological Laboratory, Woods Hole, Massachusetts 02543
}

Received June 5, 1984; Accepted August 10, 1984

\begin{abstract}
The effect of associative training on an identified putative motoneuron (MN1) in an identified visual inputoutput neural pathway was studied in Hermissenda crassicornis. The increased impulse frequency of the MN1 cell in response to a light step (MN1-LR) was found to be smaller up to $51 \mathrm{hr}$ after associative training with paired light and rotation stimuli. No change was found in animals which received these training stimuli randomly. The $\mathrm{MN1}$ activity in darkness, namely, baseline impulse frequency, spike amplitude, input resistance, and resting potential, did not change after training. 'The MN1-LR was positively correlated on retention days with the behavioral latency of the animal to enter the illuminated area of a light intensity gradient. However, the input resistance of the type B photoreceptor was inversely correlated with this behavioral latency as well as with MN1-LR. These findings suggest that the reduction of MN1-LR may be caused by the biophysical changes which have been found in the type B photoreceptor membrane. Furthermore, these findings support several other studies which indicate that specific biophysical changes in the type B photoreceptor membrane play a causal role in the observed behavioral modifications after associative training in Hermissenda.
\end{abstract}

Modification of positive phototaxis of Hermissenda crassicornis (Mollusca: Nudibranchia) can last for many days after associative training. Repetitions of paired light and rotation stimuli result in an increase in individual latencies to enter the illuminated portion of a light intensity gradient (Alkon, 1974; Crow and Alkon, 1978; Farley and Alkon, 1980; Crow and Offenbach, 1983). This change is specific to the pairing of these stimuli as random and other control treatments do not significantly alter the phototaxis. Several components of this complex behavior (Barnes and Lederhendler, 1980; Lederhendler et al., 1980) have also shown pairing-specific changes (Farley and Alkon, 1982; Crow and Offenbach, 1983; Lederhendler and Alkon, 1984), suggesting that the learned changes thus far observed by measurements of phototaxis may be reduced to specific changes in muscular activity of the foot (Lederhendler et al., 1983; Gart et al., 1983).

The patterns of use of the foot muscle for locomotion are quite diverse in opisthobranch molluscs (Thompson, 1976). A number of studies have examined this behavior from the neurobiological perspective. These have focused on withdrawal or flexion movements in the swimming behavior of Tritonia (Willows, 1967; Dorsett et al., 1973; Hoyle and Willows, 1973; Getting, 1977) and locomotion or tail withdrawal in Aplysia

\footnotetext{
${ }^{1}$ We gratefully acknowledge the help of Linda and Bob Golder for preparation of the figures, and Jeanne Kuzirian for preparation of the manuscript.

${ }^{2}$ Present address: Shinogi Research Laboratory, Shinogi and Company, Ltd., Fukushima-ku, Osaka 553 Japan.

${ }^{3}$ To whom correspondence should be addressed.
}

(Hening et al., 1979; Jahan-Parwar and Fredman, 1979; Walters et al., 1983). Abraham and Willows (1971) and Walters and Byrne (1983) have obtained evidence that such responses may be useful analogues for the study of some forms of behavioral change.

Behaviorally correlated electrophysiological changes in the Hermissenda visual system have been studied extensively (Crow and Alkon, 1980; Alkon, 1980; Crow, 1982; Farley and Alkon, 1982; West et al., 1982; Farley et al., 1983) and have consistently supported the view that a primary locus of learned change is in the type B photoreceptor of the animal's eye (Alkon, 1980; Crow and Alkon, 1980; Farley and Alkon, 1980, 1982; West et al., 1982). In specific photoreceptors which have been physically isolated from synaptic inputs, it has been found that the early $\mathrm{K}^{+}$current $\left(\mathrm{I}_{\mathrm{A}}\right)$ across the membrane is smaller in trained animals (Alkon et al., 1982; see also Alkon, 1979). More recently, $\mathrm{I}_{\mathrm{Ca}^{2+}-K^{+}}$as well as $\mathrm{I}_{\mathrm{A}}$ were shown to be substantially reduced in medial type $B$ somata from conditioned but not control animals (Farley et al., 1984; Forman et al., 1984). These changes can account for significant enhancement of the type B light response following associative training (Shoukimas and Alkon, 1980). The results of several studies indicate that such membrane changes in the $B$ cell are a cause of the behavioral modification (Crow and Alkon, 1980; Farley and Alkon, 1980, 1982; Takeda and Alkon, 1982; Farley et al., 1983). How such intrinsic primary changes in the type B cell induce the behavioral modifications via synaptic interactions, which link the afferent and efferent limbs of the visual pathway, has heretofore not been carefully examined.

Goh and Alkon (1984) have recently described the first inputoutput pathway in Hermissenda. In this pathway, the medial 
type A photoreceptor, which is inhibited by the type B photoreceptors, excites a group of interneurons. These interneurons, which are also excited by hair cells, then excite the putative motoneuron (MN1). The MN1 cell, when excited, causes turning of the animal's foot toward the ipsilateral side.

The flow of visual information through the pathway allowed us to propose a hypothetical model of how known biophysical changes in the $\mathrm{B}$ cell membrane produced by associative training may lead to the behavioral change in Hermissenda. Briefly, the enhanced light response of the $B$ cell, largely caused by reduced $\mathrm{I}_{\mathrm{A}}$ and $\mathrm{I}_{\mathrm{Ca}}{ }^{2+}{ }_{-K}{ }^{+}$current, causes more synaptic inhibition of the type A photoreceptor during a light step. Decreased A cell activity in turn causes reduced synaptic excitation of interneurons and ultimately leads to a reduction of activity in MN1, the putative motoneuron (which is synaptically excited by the interneurons). Activity changes in a number of motoneurons, including this MN1 cell, could lead to a decrease in locomolor activity of the foot. Therefore, the output effects of MN1 are seen only as a testable sample of how a motoneuron may contribute to a change of a complex behavioral pattern such as phototaxis.

To test this hypothetical sequence empirically, we examined elements in the identified pathway after training. Since activity changes in both type $A$ and type $B$ photoreceptors have been reported previously (Alkon, 1975, 1980; Alkon and Grossman, 1978; Crow and Alkon, 1980; Farley and Alkon, 1982; West et al., 1982), we chose to focus on the putative motoneuron and to study how changes in its activity correspond to changes in behavior and $B$ cell input resistance. Measurements of B cell input resistance, obtained after measuring MN1 activity, allowed us to partly assess the biophysical change of the B cell membrane (Shoukimas and Alkon, 1980; Alkon et al., 1982). A brief report of the findings in this paper has been published as an abstract (Lederhendler et al., 1982).

\section{Materials and Methods}

Animals. Hermissenda crassicornis $(\sim 2$ to $3 \mathrm{~cm}$ in length) were provided by Mr. M. Morris of Sea Life Supply (Sand City, CA). Animals were maintained individually in jars containing about $200 \mathrm{ml}$ of fresh filtered sea water. They were fed daily with pieces $(\sim 20$ to $40 \mathrm{mg})$ of clean viscera from the tunicate, Ciona intestinalis. The temperature in the jars was kept at $\sim 13$ to $14^{\circ} \mathrm{C}$, and a 12 -hr light/12-hr dark cycle was maintained by a single fluorescent lamp. The intensity of daytime illumination was approximately $7.5 \mathrm{ergs} \mathrm{cm}^{-2} \cdot \mathrm{sec}^{-1}$ measured by a radiometer (Yellow Springs Instrument Co., Yellow Springs, $\mathrm{OH}$; model 65A). All behavioral observations and electrophysiological recordings were done during the $12 \mathrm{hr}$ of illumination.

Behavioral test. To obtain base line measurements of phototaxis, Hermissenda were placed in clear plastic tubes $(1.4 \times 23 \mathrm{~cm})$ filled with fresh filtered sea water and restrained to the end of the tube by a gate. The tubes were mounted on a circular plate with their long axes directed toward the center. A fiberoptic bundle $10 \mathrm{~cm}$ above the center of the plate directed a $60^{\circ}$ cone of light from a 150 -W tungsten-halogen source, which spread along the tubes to form a horizontal gradient of illumination. The intensity of white light at the center of the tubes produced by this light source was approximately $2.3 \times 10^{4} \mathrm{ergs}^{-2} \cdot \mathrm{sec}^{-1}$. At the periphery, the intensity of white light was $\sim 20 \mathrm{ergs} \mathrm{cm}^{-2} \cdot \mathrm{sec}^{-1}$.

Prior to the base line test the animals were dark adapted for $15 \mathrm{~min}$ at which time the light was turned on and the gates were removed. The time it took each individual to cross a line $4 \mathrm{~cm}$ from the end of its tube was observed and recorded as the pretraining latency. Observations lasted $15 \mathrm{~min}$. Individuals which did not enter the light within 10 min were not further included in the study except when we attempted to correlate the behavioral latency with activity in the putative motoneuron. In this case, since we wanted to include points at the extremes of the distribution, we also examined animals which entered the light between 15 and $30 \mathrm{~min}$ as well as several which did not enter the light after $30 \mathrm{~min}$. For any single shipment of animals, the percentage of animals whose latencies were greater than 15 min never exceeded $15 \%$, and 65 to $90 \%$ entered the light within $5 \mathrm{~min}$

Training. Following the base line observations, the scores were ranked and individuals were alternately assigned to treatment groups such that the mean pretreatment latencies and distributions were similar. For the paired groups, training consisted of 50 trials a day for 3 days in which $30 \mathrm{sec}$ of diffuse white light $\left(4.6 \times 10^{4} \mathrm{ergs} \mathrm{cm}^{-2} \cdot \mathrm{sec}^{-1}\right.$ at the center area) was presented at random intervals $(0.5$ to $4 \mathrm{~min})$, together with $30 \mathrm{sec}$ of rotation $(97 \mathrm{rpm})$. Maximum rotation began about $500 \mathrm{msec}$ after the onset of light. The random group was presented with the same total number of light and rotation stimuli but on separate random programs such that no consistent association between them occurred. In fact, the program which determined random stimulus presentations contained 20 to $35 \%$ of trials in which light and rotation were partially or entirely coincident by chance alone. The presentation of light and rotation was controlled by an automated timing circuit (Tyndale and Crow, 1979).

Sampling. On the third (or last) day of training, 3 to $4 \mathrm{hr}$ after the last trial, the phototaxis of a few randomly selected individuals was tested. Different independent samples were tested after 24 and $48 \mathrm{hr}$. Some of the individuals tested behaviorally were studied electrophysiologically on the same day.

Behavioral observations followed a blind procedure whereby the treatment group of an individual was not known to the observer Similarly, electrophysiological data were gathered using a blind procedure. Animals used electrophysiologically were provided unsystematically with respect to phototactic latencies. On each day, however, we attempted to obtain recordings from each of the three treatment groups. We could find no differences in the mean latency to enter the light between the subsample which provided electrophysiological preparations and the inclusive behavioral sample from which it was drawn. In addition, we also obtained electrophysiological recordings from animals which experienced the paired and random treatments but which were never tested behaviorally (a truly random sample). The activity of MN1 and $B$ cell input resistance was not different in these animals when compared to the subsample discussed above. We felt confident, therefore, that there was no inadvertent biasing of the behavior in animals studied electrophysiologically.

In the study we thus had seven independent samples labeled: naive, paired (4, 24, and $48 \mathrm{hr}$ of retention tests), and random $(4,24$, and 48 $\mathrm{hr}$ of retention tests)

Electrophysiology. Electrophysiological recordings from isolated ner vous systems were obtained by conventional methods (Alkon, 1975) Microelectrodes filled with $3 \mathrm{M}$ potassium acetate had a resistance of about 40 to 50 megohms and were connected by a chloridized silver wire to the input stage of a high impedance preamplifier. Voltage signals were recorded on a Brush pen recorder. In order to avoid unnecessary damage to the photoreceptors, the MN1 cell was always penetrated first, and its activity was recorded. The dark characteristics of MN1 cells were measured after at least $10 \mathrm{~min}$ of dark adaptation. To measure input resistance, negative current pulses $(-0.3 \mathrm{nA}, 300$ msec duration, $2 \mathrm{~Hz}$ ) were applied through the recording electrode using a bridge circuit.

After an additional 5 min of dark adaptation, the light response to a 30 -sec light step was recorded. We used three light intensities for most preparations. The weakest light step $\left(7.5 \times 10^{2} \mathrm{ergs} \mathrm{cm}^{-2} \cdot \mathrm{sec}^{-2}\right)$ was presented first. After a 3-min interval, a moderate light step $\left(7.5 \times 10^{3}\right.$ ergs $\mathrm{cm}^{-2} \cdot \mathrm{sec}^{-1}$ ) was presented. Finally, after a 5-min interval, the maximum intensity $\left(7.5 \times 10^{4} \mathrm{ergs} \mathrm{cm}^{-2} \cdot \mathrm{sec}^{-1}\right)$ light step was presented. This order was kept constant throughout the experiment. The light was provided by a halogen lamp and the intensity was adjusted by a series of neutral density filters.

After recording the MN1 cell light responses, a single type B photoreceptor was penetrated to measure the input resistance. Following dark adaptation of at least $10 \mathrm{~min}$, the input resistance was measured in the same manner as for the MN1 cell input resistance measurement.

Data analysis. Base line frequencies of the MNI cell varied consid erably from one cell to another. The mean firing frequency in the dark, however, was not different among any of the groups compared in this experiment (see "Results"). Activity of a given MNl cell in response to light could therefore be expressed as a percentage relative to its base line frequency in the dark. The relative impulse frequency $\left(M R_{1}\right)$ during any 5-sec interval was compared to the mean of four consecutive 5 -sec intervals during the $20 \mathrm{sec}$ preceding the onset of light:

$$
M R_{t}=\frac{I F_{t}}{\left(I F_{1}+I F_{2}+I F_{3}+I F_{4}\right) / 4} \times 100
$$

where $I F_{1}$ are the firing frequencies during the four successive inter vals in the dark, $I F_{t}$ is any 5 -sec interval during the light step. 
Goh et al.

Vol. 5, No. 2, Feb. 1985

Figure 1. Behavioral measures of associative learning in Hermissenda. Top, The latencies to enter the light were greater for paired animals (open bars) during independent retention tests 4 or $24 \mathrm{hr}$ after training. Random animals (solid bars) were not different from the pretraining values. Bottom, 'The same data set treated as a ratio reflecting the degree of change for individuals with respect to their own pretest latencies. This ratio (pre-test/pre-test + post-test) yields a value of 0.5 for no change in behavior, and less than 0.5 for latencies greater than the pretest latency. The figure illustrates the direct correspondence between the raw data and the suppression ratio which has frequently been used to describe associative learning in Hermissenda. The median was chosen as an appropriate measure of central tendency because the data contained cut-off scores $\geq 30 \mathrm{~min}$.

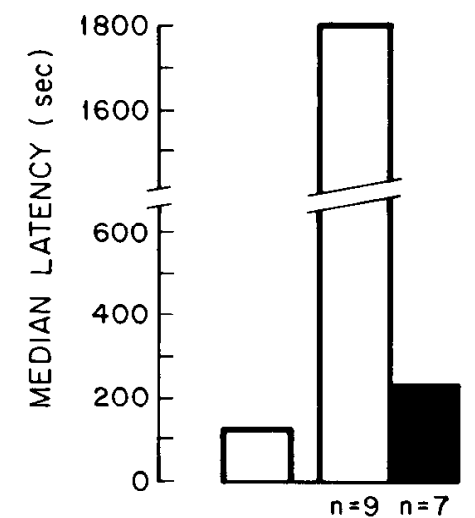

Before
Training $\quad R$
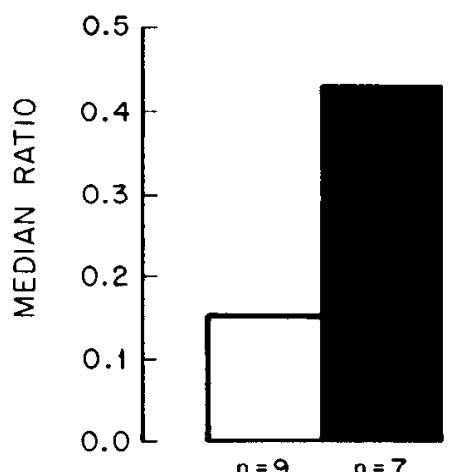

$P \quad R$

4-6HR

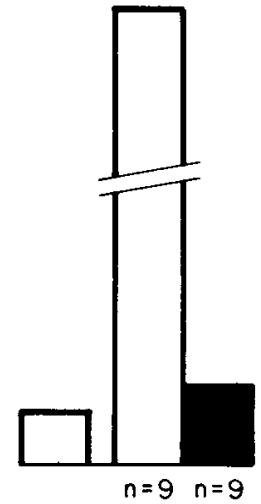

$\underset{\text { Training }}{\text { Before }} P \quad R$
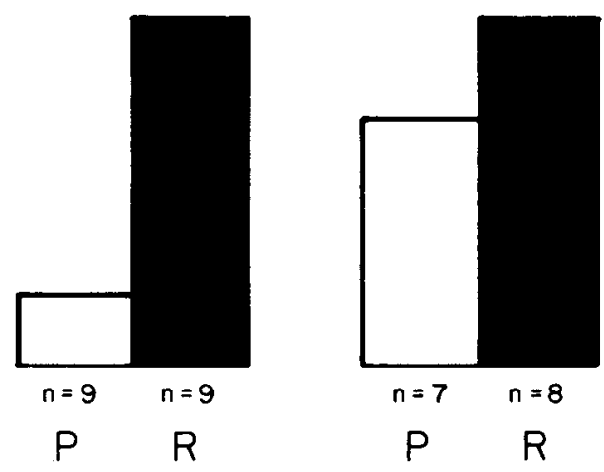

24-30 HR

$P \quad R$

$48-54 \mathrm{HR}$

TABLE I

Characteristics of the putative motoneuron (MN1) in darkness

\begin{tabular}{|c|c|c|c|c|}
\hline $\begin{array}{c}\text { Cell } \\
\text { Characteristic }\end{array}$ & $\begin{array}{c}\text { Firing } \\
\text { Frequency } \\
(\mathrm{Hz})\end{array}$ & $\begin{array}{c}\text { Resting } \\
\text { Potential } \\
\text { (mV) }\end{array}$ & $\begin{array}{c}\text { Input } \\
\text { Resistance } \\
\text { (megohms) }\end{array}$ & $\begin{array}{l}\text { Spike } \\
\text { Amplitude } \\
\text { (mV) }\end{array}$ \\
\hline Naive & $\begin{array}{c}9.64 \pm 3.02^{a} \\
(22)^{b}\end{array}$ & $\begin{array}{c}58.05 \pm 3.65 \\
(20)\end{array}$ & $\begin{array}{c}53.04 \pm 14.62 \\
(21)\end{array}$ & $\begin{array}{c}81.05 \pm 4.86 \\
(21)\end{array}$ \\
\hline \multicolumn{5}{|l|}{ Random } \\
\hline $4 \mathrm{hr}$ & $\begin{array}{c}11.04 \pm 3.99 \\
(10)\end{array}$ & $\begin{array}{c}57.11 \pm 2.15 \\
(9)\end{array}$ & $\begin{array}{c}45.00 \pm 14.26 \\
(9)\end{array}$ & $\begin{array}{c}79.80 \pm 6.89 \\
(10)\end{array}$ \\
\hline $48 \mathrm{hr}$ & $\begin{array}{c}11.03 \pm 3.52 \\
(12)\end{array}$ & $\begin{array}{c}56.42 \pm 4.12 \\
(12)\end{array}$ & $\begin{array}{c}48.61 \pm 23.99 \\
(11)\end{array}$ & $\begin{array}{c}78.75 \pm 8.38 \\
(12)\end{array}$ \\
\hline \multicolumn{5}{|l|}{ Paired } \\
\hline $4 \mathrm{hr}$ & $\begin{array}{c}14.08 \pm 8.19 \\
(12)\end{array}$ & $\begin{array}{c}57.64 \pm 2.42 \\
\text { (11) }\end{array}$ & $\begin{array}{c}42.97 \pm 14.21 \\
(10)\end{array}$ & $\begin{array}{c}79.46 \pm 5.73 \\
(11)\end{array}$ \\
\hline $24 \mathrm{hr}$ & $\begin{array}{c}12.97 \pm 4.88 \\
(11)\end{array}$ & $\begin{array}{c}54.90 \pm 3.28 \\
(10)\end{array}$ & $\begin{array}{c}47.70 \pm 10.60 \\
(11)\end{array}$ & $\begin{array}{c}76.11 \pm 6.74 \\
(9)\end{array}$ \\
\hline
\end{tabular}

${ }^{a}$ Mean \pm S.D.

${ }^{b}$ Numbers in parentheses, number of cells.

Statistical analysis was done by computer, using the BMDP statistical package (UCL $\Lambda$ Press) unless otherwise indicated. Correlations among small groups were done using a Spearman rank correlation $\left(r_{s}\right)$.

\section{Results}

Behavior. Within-group differences were assessed using a one-tailed Wilcoxon test. Paired animals showed significantly greater latencies to enter the light $4 \mathrm{hr}(p<0.005)$ and $24 \mathrm{hr}$ $(p<0.005)$ after the end of training, whereas random animals did not change significantly compared to their pretraining tests. No differences in pretraining scores were found between the animals which were to receive paired or random treatments. Between-group differences, assessed with a Mann-Whitney $U$ 
TABLE II

Type B photoreceptor characteristics in darkness

\begin{tabular}{|c|c|c|c|c|}
\hline Naive & Retention & Paired & Random & $p$ \\
\hline \multicolumn{5}{|c|}{ Resting potential (mV) } \\
\hline \multirow[t]{3}{*}{$\begin{array}{c}53.70 \pm 3.50^{a} \\
(13)^{c}\end{array}$} & $4 \mathrm{hr}$ & $\begin{array}{c}53.33 \pm 5.77 \\
(8)\end{array}$ & $\begin{array}{c}56.60 \pm 5.46 \\
(8)\end{array}$ & $\mathrm{NS}^{b}$ \\
\hline & $24 \mathrm{hr}$ & $\begin{array}{c}55.33 \pm 4.08 \\
(9)\end{array}$ & $\begin{array}{c}54.50 \pm 3.63 \\
(10)\end{array}$ & NS \\
\hline & $48 \mathrm{hr}$ & $\begin{array}{c}52.50 \pm 2.74 \\
(8)\end{array}$ & $\begin{array}{c}54.67 \pm 3.27 \\
(8)\end{array}$ & NS \\
\hline \multicolumn{5}{|c|}{ Input resistance (megohms) } \\
\hline \multirow[t]{3}{*}{$\begin{array}{c}57.80 \pm 20.47 \\
(13)\end{array}$} & $4 \mathrm{hr}$ & $\begin{array}{c}76.30 \pm 15.10 \\
(8)\end{array}$ & $\begin{array}{c}62.06 \pm 10.39 \\
(8)\end{array}$ & $<0.025$ \\
\hline & $24 \mathrm{hr}$ & $\begin{array}{c}79.94 \pm 16.00 \\
(10)\end{array}$ & $\begin{array}{c}55.67 \pm 10.75 \\
(11)\end{array}$ & $<0.025$ \\
\hline & $48 \mathrm{hr}$ & $\begin{array}{c}69.63 \pm 17.87 \\
\text { (11) }\end{array}$ & $\begin{array}{c}55.14 \pm 8.84 \\
(9)\end{array}$ & $<0.025$ \\
\hline
\end{tabular}

${ }^{a}$ Values are mean \pm S.D.

${ }^{b} \mathrm{NS}$, not significant.

${ }^{\mathrm{C}}$ Numbers in parentheses, number of cells.

test, indicated that paired animals were significantly slower than the random animals $4 \mathrm{hr}(p<0.002)$ and $24 \mathrm{hr}(p<$ 0.002 ) after the conclusion of training. Complementary results were found when we tested the index of relative change (the suppression ratio) which has been used in previous reports (Fig. 1).

Cell characteristics in darkness. We characterized the resting activity of the putative motoneuron (MN1) with measurements of firing frequency, resting potential, input resistance, and spike amplitude. Possible changes in these properties following associative training were assessed using analysis of variance (ANOVA) and post hoc $t$ tests. There were no statistically significant between-group differences for any of the MN1 cell characteristics which we studied (Table I). We also measured the resting potential and input resistance of the type B photoreceptor in darkness. Possible changes in these measures after associative training were assessed statistically using ANOVA for independent observations for each post-training retention period $(4,24$, or $48 \mathrm{hr}$ ) by each treatment (paired or random).

Resting potential did not differ among the groups (Table II). However, significant effects on input resistance were found due to treatment alone $\left(F_{(1,51)}=34.48 ; p<.0001\right)$ and retention alone $\left(F_{(2,51)}=3.64 ; p<0.05\right)$. In addition, an effect on input resistance due to the interaction of treatment and retention period was also found $\left(F_{2,51}=4.33 ; p<0.05\right)$. The post hoc $t$ test $(p<0.05)$ indicated that paired groups always had higher input resistance values than did the random groups. Furthermore, we found that the paired animals had significantly greater input resistance values than did naive animals up to $24 \mathrm{hr}$ after training, but random animals did not differ from the naive control group (Table II).

Characteristics of $M N 1$ in response to light. The light response of the putative motoneuron (MN1-LR) has at least two phases. An initial phase consists of an increase in impulse frequency during the light step. Another phase consists of rhythmic bursting activity (Goh and Alkon, 1984). Figure 2, which shows a histogram of impulse activity from naive animals, illustrates these two phases. In response to a 30 -sec light step we observed a general increase in impulse activity which persists for some time after the end of stimulation. Illumination of maximum intensity produced a marked increase in impulse activity which had a brief latency of onset (initial phase). In Figure 2 the beginning of a bursting phase is seen 45 sec after the onset of the most intense light stimulus.

In the present study we focused on the changes in activity during the first $5 \mathrm{sec}$ of the initial phase. We chose to do this for the following reasons: (1) the initial increase in impulse activity is most readily observed during this period; (2) the increase in activity during this period is produced the identified visual pathway, whereas the other components of the MN1-LR may depend on additional inputs; and (3) measurements of activity during this interval are least likely to include false or misleading contributions by the bursting phase.

The bursting activity is, in itself, potentially interesting. As reported previously (Goh and Alkon, 1984), it may be characterized with a long latency of onset and persistence for several minutes; in addition, it was observed to occur more frequently in response to higher levels of light intensity. Nevertheless, the causes or sources of the bursting are not known and we did not pursue this problem in the present paper.

Effects of training on $M N 1-L R$. The impulse frequency of the putative motoneuron during the 5-sec interval after light onset was lower in animals which received associative training. Figure 3 shows the post-training responses for two 5 -sec intervals immediately before illumination and during the 5-sec interval after stimulus onset. There were no differences in dark activity among the seven treatment groups. A one-way ANOVA indicated that significant differences among the seven groups did exist $\left(F_{(6,85)}=4.92 ; p<0.001\right)$. In the responses during the first $5 \mathrm{sec}$ of illumination, post hoc $t$ tests showed that, whereas there were no differences between the random and naive groups, paired animals had significantly lower responses to illumination compared to the random animals for each period of retention.

We found the degree of this reduction in MN1-LR to be dependent upon the intensity of illumination. As shown in Figure 4, MN1-LR changes linearly with the logarithm of illumination intensity over the range of stimulation which we observed. As a result, it seems that differences between treat-

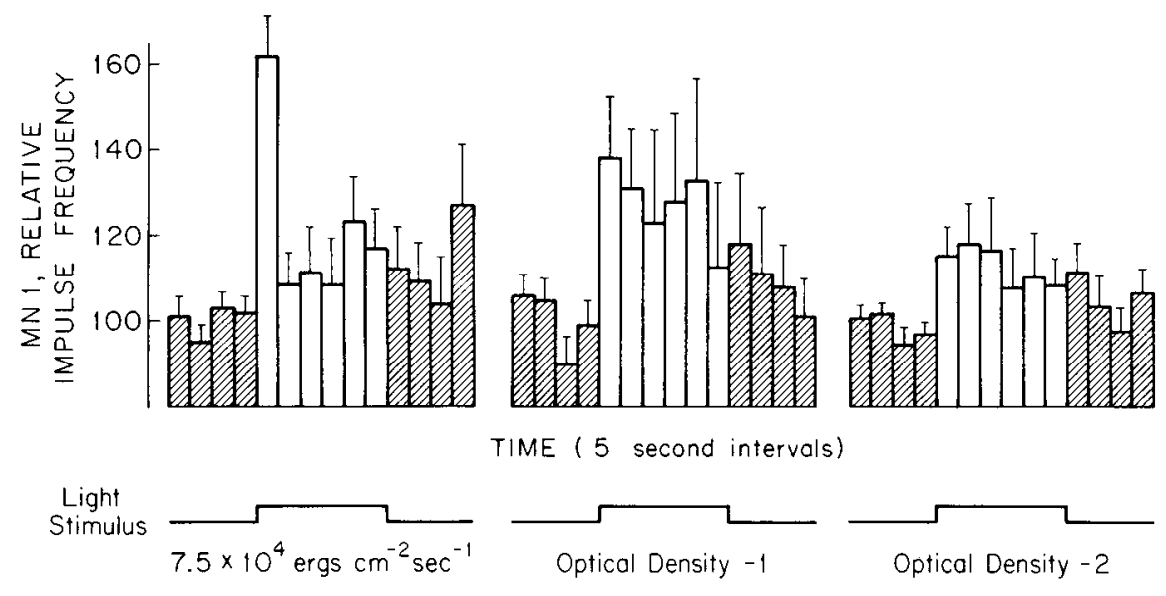

Figure 2. The change in impulse frequency of MN1 cells from naive animals in response to light stimulation. The frequency is shown as a mean percentage of change for each 5 -sec interval plus the standard deviation (see "Materials and Methods"). 
Figure 3. Comparison of MN1 cell im pulse frequency between paired and random treatments. Each bar is the mean percentage of change for a 5 -sec interval. Whereas impulse frequency in darkness was not different, paired animals showed significantly less activity in response to light at least $48 \mathrm{hr}$ after training. The probability levels are based on $t$ tests comparing independent samples during each period of retention. The intensity of light stimulation was $7.5 \times 10^{4} \mathrm{ergs}$ $\mathrm{cm}^{-2} \cdot \mathrm{sec}^{-1}$. Error bars are standard deviations.

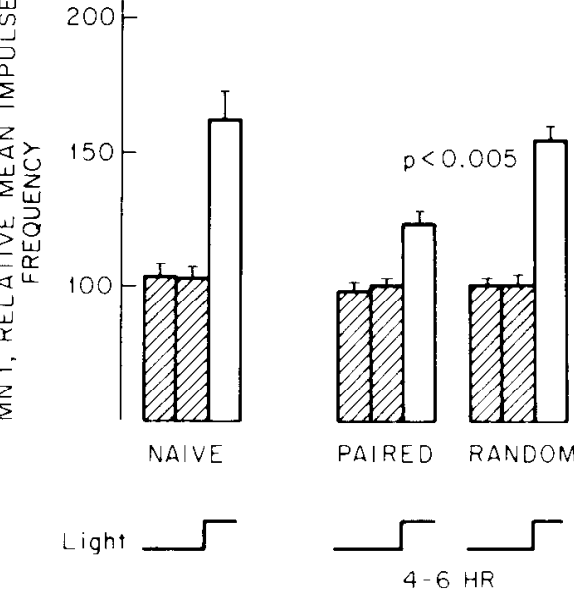

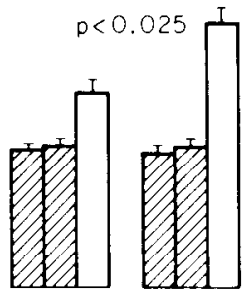

PAIRED RANDOM

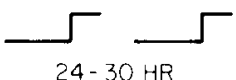

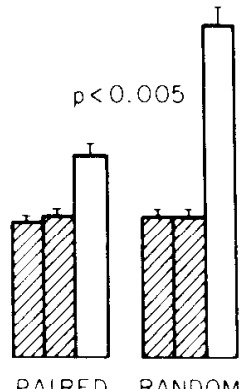

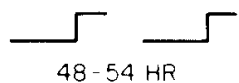

RETENTION

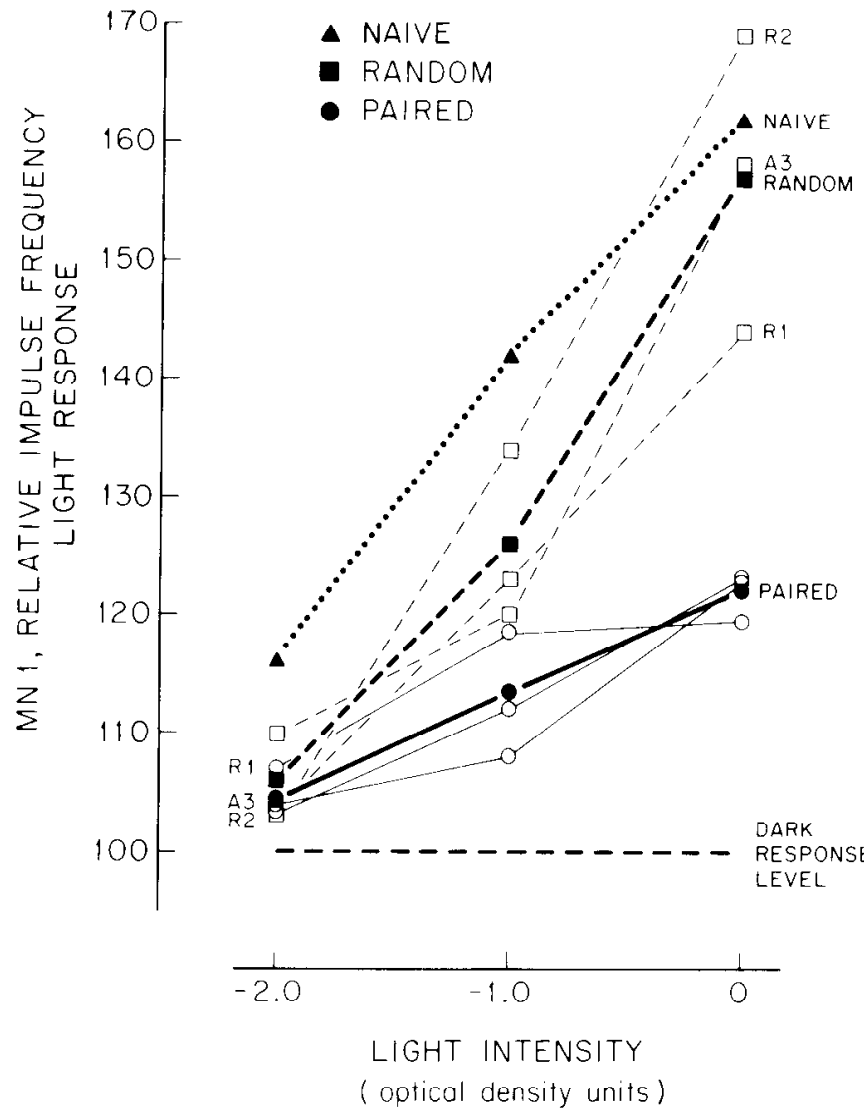

Figure 4. The relationship between the MN1 cell light response and stimulus intensity for the treatment groups observed in this study. Impulse frequency in the paired groups $(O, 0)$ was inhibited relative to random $(\square, \boldsymbol{\square})$ and naive $(\Delta, \boldsymbol{\Delta})$ groups. These differences were more clearly seen at levels of light intensity which elicited larger light responses in MN1. Light lines are mean values for either paired or random groups during each period of retention. Heavy lines are the pooled mean values for each treatment group. $A 3,4$ to $6 \mathrm{hr}$ of retention; $R 1,24$ to $30 \mathrm{hr}$ of retention; $R 2,48$ to $54 \mathrm{hr}$ of retention.

ment groups may be masked at levels of illumination which produce smaller increases in impulse activity.

The rclationship between associative learning and the intensity dependence of MN1-LR was assessed by means of ANOVA between paired and random treatments for three repeated measures of $\mathrm{MN1}$ impulse activity (the relative impulse fre- quency for the three successive 5-sec intervals starting $10 \mathrm{sec}$ before light onset). For each level of light intensity, each retention period $(4,24$, or $48 \mathrm{hr})$ was analyzed separately.

Significant main effects, as well as interaction effects, were found for each retention period only with the greatest level of illumination. Four to $8 \mathrm{hr}$ after the end of training, the ANOVA revealed a significant difference between the paired and random treatment groups $\left(F_{(1,20)}=7.57 ; p=0.012\right)$. A post hoc $t$ test showed that the MN1-LR was significantly lower in the paired animals $(t=2.99 ; p<0.05)$. The interaction effect between the MN1-LR and the treatments was also statistically significant $\left(F_{(2,40)}=7.80 ; p<0.01\right)$. Twenty-four hours after the end of training, the ANOVA indicated that there was no difference due to paired or random treatment $\left(F_{(1,22)}=3.86 ; p<0.07\right)$. However, since an interaction effect between the light response and treatment was statistically significant $\left(F_{(2,44)}=3.51 ; p<\right.$ 0.05 ), we examined the treatment groups with a $t$ test and found that the MN1-LR was significantly lower for the paired group in comparison to the random group $(t=2.18 ; p<0.025)$.

Forty-eight hours after the end of training, the ANOVA revealed a significant difference between the paired and random treatment groups $\left(F_{(1,24)}=10.98 ; p<0.005\right)$. A post hoc $t$ test indicated that the MN1-LR was significantly lower in paired animals $(t=3.14 ; p<0.005)$. The interaction effect of MN1 $L R$ with the paired and random treatments was also statistically significant $\left(F_{(2,48)}=7.50 ; p<0.005\right)$.

No main effects due to treatment were found for low or intermediate levels of illumination. However, a significant in teraction effect of treatment and the light response was found when the animals from all of the retention days were combined $\left(F_{(4,160)}=4.38 ; p<0.005\right)$.

For the lowest level of illumination the increase in impulse activity of the putative motoneuron could be discerned above the rate in darkness when all cases were combined $\left(F_{(2,158)}=\right.$ $11.30 ; p<0.001)$. For smaller sample sizes the light response could not be detected reliably, and, therefore, any changes due to associative learning could not be assessed in a meaningful way.

Relationships among behavior, MN1-LR, and the type B photoreceptor. The latency of Hermissenda to enter the light, the light response of the putative motoneuron, and the input resistance of the type B photoreceptor each showed pairingspecific changes after training. Further analysis of these variables suggests that they are related to one another in a manner predicted by: (1) our knowledge of one specific series of synaptic connections between the photoreceptors and the putative mo- 


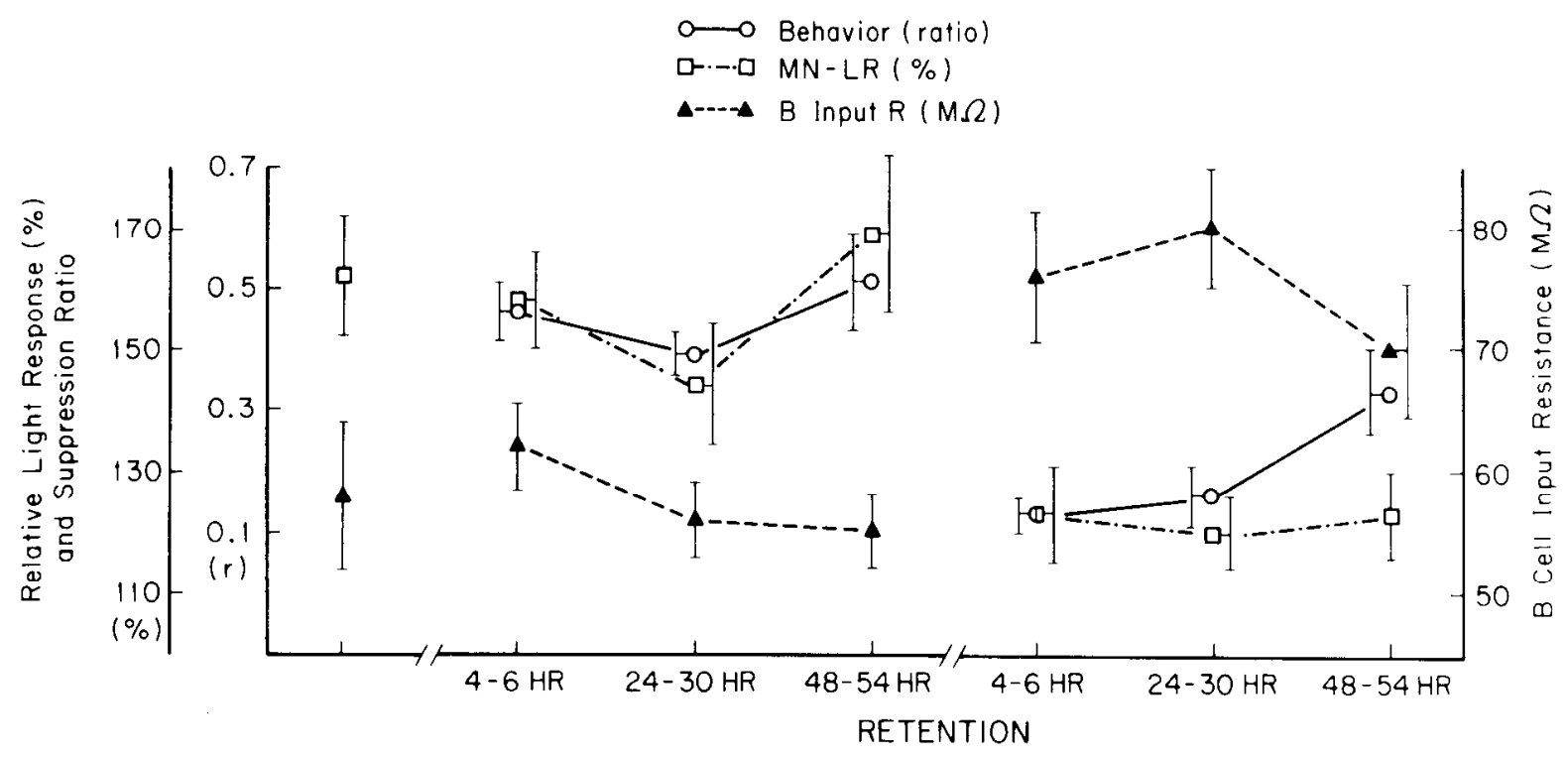

NAIVE

RANDOM

PAIRED

Figure 5. Relationship between changes in behavior, MN1 cell light response, and type B photoreceptor input resistance as a result of associative learning. Compared to random animals, paired animals showed a suppression of phototaxis and a reduction in MN1 impulse activity, whereas the input resistance of the type B photoreceptor increased. Error bars are standard deviations for the electrophysiological measures and standard error of the mean for the behavior.

toneuron, and (2) our hypothesis of some contributing role for MN1 in light-dependent movement, particularly phototaxis.

In an independent study of 15 previously untested animals, including 7 animals with latencies to enter the light greater than $15 \mathrm{~min}$ (not normally included in samples of paired, random, or naive treatments), we obtained responses of the putative motoneuron to a light stimulus of maximum intensity. We found the MN1-I.R to he inversely correlated with latency $\left(r_{s}=-0.48 ; p<0.05\right)$. Since animals from paired and random treatment groups cluster in different regions of the scatterplot both with respect to latency (median test: $\chi^{2}=4.82 ; p<0.05$ ) and with respect to MN1-LR $\left(\chi^{2}=9.44 ; p<0.01\right)$, the possibility of correlation between these variables was assessed by combining the values from all treatment groups. Again an inverse correlation was found ( $r=-0.39 ; d f=48 ; p<0.05$ ).

Additional evidence supporting the hypothesis of a role of the putative motoneuron in the associative learning was found in a corresponding positive correlation between MN1-LR and the suppression ratio for all paired and random animals $(r=$ $0.57 ; p<0.01 ; N=35$ ).

After training, activity of the putative motoneuron was found to be inversely correlated with the type B cell input resistance in response to both maximum and moderate levels of light intensity $(r=-0.43$ and $r=-0.40$, respectively; $d f=71 ; p<$ 0.01 ). It is interesting that this correlation was not statistically significant for the random or naive samples alone, whereas, within the paired group it was $(r=-0.46 ; d f=30 ; p<0.05)$. This difference among the groups may be indicative of the previously demonstrated increases in B cell input resistance and light-elicited depolarization which occur with associative learning.

Among naive animals, the latency to enter the light and $\mathrm{B}$ cell input resistance were positively correlated $\left(r_{s}=+0.57 ; \mathrm{N}\right.$ $=12 ; p<0.05$ ). After training, the $\mathrm{B}$ cell input resistance was positively correlated with the latency to enter the light when the data of all of the groups were combined $(r=0.46 ; d f=37$; $p<0.05)$. The corresponding suppression ratios were inversely correlated with $B$ cell input resistance for the paired and random groups $(r=-0.50 ; d f=25 ; p<0.05)$.
The association of these three variables is illustrated in Figure 5.

\section{Discussion}

The visual pathway, through which the initial phase of the MN1-LR is produced, consists of five neuron types. The medial type A photoreceptor, which is inhibited by the medial type B photoreceptor, excites a group of interneurons. These interneurons, which are also excited by hair cells in statocysts, excite the putative motoneuron ( $\mathrm{MN} 1$ cell). It has been demonstrated that the type $\mathrm{B}$ photoreceptor shows an enhanced light response after training (Crow and Alkon, 1980; Farley and Alkon, 1982; West et al., 1982). Therefore, if the training regimen has a significant primary effect on the type $B$ photoreceptor, one would expect a reduction of $\mathrm{MN} 1-\mathrm{I} R$ during retention days following the training session. The light response of the MN1 cell was indeed reduced in the animals which received a training regimen with paired light and rotation. The light response was consistently smaller in paired than in random or naive animals throughout retention days, although a significant difference was not detected with weaker light stimuli.

There are several observations which support the hypothesis that the suppression of MN1-LR is caused by the enhanced light response of the type $\mathrm{B}$ photoreceptor. First of all, the change of the MN1 cell activity was light dependent. None of the four characteristics of MN1 activity in darkness which we measured, namely, base line firing frequency, resting potential, input resistance, and spike amplitude, were found to change after training. The constancy of the base line firing frequency especially suggests that the dark activity of elements presynaptic to the MN1 cell (Goh and Alkon, 1984), such as the interneurons, are not affected by the training procedure. Since the type B photoreceptors are known to inhibit type A photoreceptors monosynaptically (Alkon, 1973a; Alkon and Grossman, 1978), the enhanced B cell light response will cause increased synaptic inhibition of the type A cell during and following its response to light. Furthermore, it has been directly demonstrated that current-elicited increases of impulse fre- 
quency of two type $B$ photoreceptors reduce the MN1 cell activity during a light step (Goh and Alkon, 1984).

Additional support for this sequence of changes during the expression of learning-induced changes of the visual pathway was provided by the correlation between $B$ cell input resistance and MN1-LR. The enhancement of the $B$ cell light response after training was associated with an increased input resistance (Farley and Alkon, 1982; West et al., 1982). This increase of resistance has been attributed, at least in part, to the decrease of early $\mathrm{K}^{+}$current $\left(I_{\mathrm{A}}\right)$ and the decrease of a $\mathrm{Ca}^{2+}$-dependent $\mathrm{K}^{+}$current $\left(\mathrm{I}_{\mathrm{Ca}^{2+}-\mathrm{K}^{+}}\right)$across the $\mathrm{B}$ cell membrane after training. This reduction of $\mathrm{K}^{+}$currents intrinsic to the type $\mathrm{B}$ soma membrane was considered to be important in enhancing the $\mathrm{B}$ cell light response (Alkon et al., 1982a, b; Shoukimas and Alkon, 1980). The inverse correlation, which was observed between the $B$ cell input resistance and MN1-LR, not only supports the notion that the type $B$ photoreceptor plays a causal role in reducing MN1-LR, but also suggests a biophysical basis within the $\mathrm{B}$ cell membrane for the learning-induced changes of activity of the putative motoneuron (MN1).

Although the precise mechanism is not known at this point, the reduction of the MN1-LR may be partly responsible for the slower phototactic behavior in associatively trained animals. This is possible since the MN1 impulse is known to produce turning of the animal's foot by causing contractions on the ipsilateral side of the foot (Goh and Alkon, 1984). It seems likely, therefore, that an MN1 inpulse train may cause headturning toward the ipsilateral side in unrestrained animals. Such responses are consistent with positive phototaxis in which animals perform a series of corrective movements while locomoting toward illuminated areas (Fraenkel and Gunn, 1961). Supporting a role for $\mathrm{MN} 1$ activity in phototaxis is the fact that a positive correlation was found in this study between MN1-LR and the latency to enter the illuminated area in the animals studied here (i.e., the smaller the light response, the slower the animal, and the less effective the phototaxis).

Other mechanisms may also contribute to the learning-induced reduction of MN1-LR. Changes intrinsic to type A photoreceptors (Richards et al., 1983) and possibly other cells could contribute to some of the MN1 changes observed here. However, a semipermanent reduction of voltage-dependent $\mathrm{K}^{+}$ currents $\left(I_{\mathrm{A}}\right.$ and $\left.\mathrm{I}_{\mathrm{Ca}}{ }^{2+} \cdot{ }_{\mathrm{K}}^{+}\right)$and the resulting increase of input resistance within the type $B$ soma provide a clear mechanism for storing associatively learned behavior, and, as we have analyzed it here, the output of the visual pathway significantly reflects the encoding processes which occur in the type B cell at the input stage of the pathway.

\section{References}

Abraham, F. D., and A. O. D. Willows (1971) Plasticity of a fixed action pattern in the sea slug, Tritonia diomedia. Commun. Behav. Biol. (A) 6: 271-280.

Alkon, D. L. (1973a) Neural organization of a molluscan visual system. J. Gen. Physiol. 61: 444-461.

Alkon, D. L. (1973b) Intersensory interactions in Hermissenda. J. Gen. Physiol. 64: 70-84.

Alkon, D. L. (1974) Associative training of Hermissenda. J. Gen. Physiol. 64: 70-84.

Alkon, D. L. (1975) Neural correlates of associative training in Hermissenda. J. Gen Physiol. 65: 46-56.

Alkon, D. L. (1979) Voltage-dependent calcium and potassium ion conductances: A contingency mechanism for an associative learning model. Science 205: 810-816.

Alkon, D. L. (1980) Membrane depolarization accumulates during acquisition of an associative behavioral change. Science 210: 13751376 .

Alkon, D. L., and Y. Grossman (1978) Long-lasting depolarization and hyperpolarization in eye of Hermissenda. J. Neurophysiol. 41:13281342.

Alkon, D. L., I. Lederhendler, and J. J. Shoukimas (1982a) Primary changes of membrane currents during retention of associative learning. Science 215: 693-695.

Alkon, D. L., J. J. Shoukimas, and E. Heldman (1982b) Calcium mediated decrease of a voltage-dependent potassium current. Biophys. J. 40: 245-250.

Barnes, E., and I. Lederhendler (1980) Dark-adaptation effects on photobehavior of Hermissenda crassicornis (Gastropoda: nudihranchia). Biol. Bull. 159: 479.

Crow, T. (1982) Sensory neuronal correlates of associative learning in Hermissenda. Soc. Neurosci. Abstr. 8: 824.

Crow, T. J., and D. L. Alkon (1978) Retention of an associative behavioral change in Hermissenda. Science 201: 1239-1241.

Crow, T. J., and D. L. Alkon (1980) Associative behavioral modification in Hermissenda: Cellular correlates. Science 209: 412-414.

Crow, T., and N. Offenbach (1983) Modification of the initiation of locomotion in Hermissenda: Behavioral analysis. Brain Res. 271: 301-310.

Dorsett, D. A., A. O. D. Willows, and G. Hoyle (1973) The neuronal basis of behavior in Tritonia. IV. The central origin of a fixed action pattern demonstrated in the isolated brain. d. Neurobiol. 4: 287-300.

Farley, J. and D. L. Alkon (1980) Neural organization predicts stimulus specificity for a retained associative behavioral change. Science 210: 1373-1375

Farley, J. and D. L. Alkon (1982) Associative neural and behavioral change in Hermissenda: Consequences of nervous system orientation for light- and pairing-specificity. J. Neurophysiol. 48: 785-807.

Farley, J., W. G. Richards, L. U. Ling, E. Liman, and D. L. Alkon (1983) Membrane changes in a single photoreceptor cause associative learning in Hermissenda. Science 221: 1201-1203.

Farley, J., M. Sakakibara, and D. L. Alkon (1984) Associative-training correlated changes in $\mathrm{I}_{\mathrm{Ca}-\mathrm{K}}$ in Hermissenda type $\mathrm{B}$ photoreceptors. Soc. Neurosci. Abstr. 10: 270.

Forman, R., D. L. Alkon, M. Sakakibara, J. Harrigan, I. Lederhendler, and J. Farley. (1984) Changes in $I_{A}$ and $I_{C}$ but not $I$ accompany retention of conditioned behavior in Hermissenda. Soc. Neurosci. Abstr. 10: 121

Fraenkel, G. S. and D. L. Gunn (1961) The Orientation of Animals. New York: Dover.

Gart, S., I. Lederhendler, and D. L. Alkon (1983) An infrared macrophotographic technique for quantifying the behavioral response to rotation of the gastropod Hermissenda crassicornis. Biol. Bull. 165: $525-526$.

Getting, P. A. (1977) Neuronal organization of escape swimming in Tritonia. J. Comp. Physiol. 121: 325-342.

Goh, Y., and D. L. Alkon (1984) Sensory, interneuronal, and motor interactions within Hermissenda visual pathway. J. Neurophysiol. 52: $156-169$

Hening, W. A., E. T. Walters, T. J. Carew, and E. R. Kandel (1979) Motorneuronal control of locomotion in Aplysiu. Brain Res. 179 . 231-253.

Hoyle, G., and A. O. D. Willows (1973) Neuronal basis of behavior in Tritonia. II. Relationship of muscular contraction to nerve impulse pattern. J. Neurobiol. 4: 239-254.

Jahan-Parwar, B., and S. M. Fredman (1979) Neural control of locomotion in Aplysia: Role of the central ganglia. Behav. Neural Biol. 27: $39-58$.

Lederhendler, I., and D. L. Alkon (1984) Reduced withdrawal from shadows: An expression of primary neural changes of associative learning in the nudibranch Hermissenda crassicornis. Soc. Neurosci. Abstr. 10: 270.

Lederhendler, I. I., E. S. Barnes, and D. L. Alkon (1980) Complex responses to light of the nudibranch Hermissenda crassicornis. Behav. Neural Biol. 28: 218-230.

Lederhendler, I., Y. Goh, and D. L. Alkon (1982) Type B photoreceptor changes predict modification of motorneuron responses to light during retention of Hermissenda associative conditioning. Soc. Neurosci. Abstr. 8: 824.

Lederhendler, I. I., S. Gart, and D. L. Alkon (1983) Associative learning in Hermissenda crassicornis (Gastropoda): Evidence that light (the CS) takes on characteristics of rotation (the UCS). Biol. Bull. 165: 528-529.

Richards, W., J. Farley, and D. L. Alkon (1983) Extinction of associative learning in Hermissenda: Behavior and neural correlates. Soc Neurosci. Abstr. 9: 916.

Shoukimas, J. J., and D. L. Alkon (1980) Voltage-dependent, early 
outward current in a photoreceptor of Hermissenda crassicornis. Soc. Neurosci. Abstr. 6: 17.

Takeda, T., and D. L. Alkon (1982) Correlated receptor and motorneuron changes during retention of associative learning of Hermissenda crassicornis. Comp. Biochem. Physiol. (A) 73: 151-157.

Thompson, T. E. (1976) Biology of Opisthobranch Molluscs, The Ray Society, London.

Tyndale, C. L., and T. J. Crow (1979) An IC control unit for generating random and nonrandom events. IEEE Trans. Biomed. Eng. 26: 649655.
Walters, E. T., and J. H. Byrne (1983) Associative conditioning of single sensory neurons suggests a cellular mechanism for learning. Science 219: 405-408.

Walters, E. T., J. H. Byrne, T. J. Carew, and E. R. Kandel (1983) Mechanoafferent neurons innervating tail of Aplysia. I. Response properties and synaptic connections. J. Neurophysiol. 50: 1522-1542.

West, A., E. Barnes, and D. L. Alkon (1982) Primary changes of voltage responses during retention of associative learning. J. Neurophysiol 48: $1243-1255$.

Willows, A. O. D. (1967) Behavioral acts elicited by stimulation of single identifiable nerve cells. Science 157: $570-574$. 